\title{
KORELASI PENDIDIKAN DAN UMUR DENGAN PENGETAHUAN IBU HAMIL TRIMESTER III TENTANG ASI EKSKLUSIF
}

\author{
CORRELATION BETWEEN EDUCATION AND AGE \\ WITH KNOWLEDGE OF PREGNANT WOMEN AT THIRD \\ TRIMESTER ABOUT EXCLUSIVE BREAST MILK
}

\author{
Eva Putriningrum ${ }^{1}$, Nurul Khasanah \\ STIKES Jenderal Achmad Yani Yogyakarta \\ 1Email : vakovedant@yahoo.com
}

\begin{abstract}
ABSTRAK
ASI eksklusif merupakan pemberian ASI saja pada bayi sampai usia enam bulan tanpa tambahan cairan ataupun makanan lainnya. Cakupan ASI eksklusif di Kota Yogyakarta belum mencapai angka yang diharapkan yaitu 80\%, salah satunya adalah di Puskesmas Kotagede I. Rendahnya cakupan keberhasilan pemberian ASI eksklusif dipengaruhi banyak hal, salah satunya adalah kurangnya informasi mengenai ASI atau salah dalam memahami informasi mengenai ASI. Tujuan penelitian ini adalah untuk menganalisis korelasi antara pendidikan dan umur, dengan pengetahuan ibu hamil trimester III tentang ASI eksklusif di Puskesmas Kota Gede I Yogyakarta. Desain penelitian ini menggunakan survey analitik dengan rancangan Cross Sectional, dengan sampel 30 ibu hamil Trimester III dan menggunakan teknik sampling jenuh. Uji statistik yang digunakan adalah Chi Square. Hasil penelitian menunjukkan terdapat korelasi antara pendidikan dengan pengetahuan dengan nilai $p$ sebesar 0,019 dan nilai odd ratio sebesar 9,33, dan terdapat korelasi antara umur dengan pengetahuan dengan nilai $p$ sebesar 0,004 dan nilai odd ratio sebesar 20,0. Dapat disimpulkan bahwa terdapat korelasi antara pendidikan dan umur, dengan pengetahuan tentang ASI eksklusif.
\end{abstract}

Kata Kunci : Pendidikan, Umur, Pengetahuan, ASI Eksklusif.

\section{ABSTRACT}

The exclusive breast milk is feed baby only with the breast milk until the age of six months without any additional liquid or food. The scope of exclusive breast milk in Yogyakarta does not reach the expected rate amount $80 \%$, one of them was in Public Health Centre of Kota Gede I. Low rate success of exclusive breast milk feeding was affected by many factors, such as lack of information regarding breast milk and misunderstanding of information about breast milk. This research aims to analyze the correlation between education and age, with knowledge of pregnant women at third trimester about exclusive breast milk in Public Health Centre of Kota Gede I, Yogyakarta. The design of this research used analytic survey with a Cross-Sectional design and 30 pregnant women at third trimester as samples, with the saturated sampling technique. The statistical test used Chi-Square Test. This research showed that there is a correlation between education and knowledge with p-value of 0,019 and odd ratio value of 9,33; there is a correlation between age and knowledge with p-value of 0,004 and odd ratio value of 20,0. It can be concluded that there is a correlation between education and age, with knowledge about exclusive breast milk.

Keywords: Education, Age, Knowledge, Exclusive Breast Milk

\section{PENDAHULUAN}

Air Susu Ibu (ASI) adalah zat gizi yang berperan penting untuk kelangsungan kehidupan bayi, karena ASI merupakan satu-satunya nutrisi terbaik untuk bayi, terutama pada enam 
bulan awal kehidupannya

(Proverawati\&Rahmawati, 2010).

Program Pemerintah terhadap

Peningkatan Pemberian ASI

mempunyai dampak positif terhadap

status gizi bayi (Depkes RI, 2013).

Pencapaian target ASI eksklusif di Indonesia baru mencapai kisaran $42 \%$, dan tentunya angka tersebut masih kurang dari harapan pemerintah yaitu sebesar 80\% (SDKI, 2012). Sedangkan, data yang didapat dari Dinas Kesehatan provinsi pada tahun 2013, menunjukkan bahwa pemberian ASI eksklusif pada bayi usia 0-6 bulan sebanyak 54,3\%, dan hanya terdapat 19 provinsi yang dapat memberikan ASI eksklusif di atas angka tersebut (Pusdatin, 2015).

Belum terpenuhinya pencapaian target ASI eksklusif ini dipengaruhi banyak hal di antaranya adalah kurangnya atau salah dalam mencerna informasi yang di dapat mengenai ASI, maraknya iklan mengenai berbagai jenis susu formula, ASI tidak keluar (sedikit), dan kebanyakan orang beranggapan bahwa bayi yang di berikan tambahan susu lebih gemuk di banding bayi yang memperoleh ASI eksklusif. Peranan tenaga kesehatan sangat di butuhkan demi mencapainya program ASI eksklusif (Budiasih, 2008).
Masa kehamilan adalah waktu yang terbaik untuk meluruskan persepsi yang salah dan menggali kesenjangan informasi. Bidan dapat mulai mendiskusikan rencana pemberian makanan bayi setelah melahirkan, terutama tentang pemberian ASI. Pengalaman menyusui pada keluarga ataupun pengalaman sebelumnya penting untuk dibahas. Selanjutnya bidan memberikan dukungan, klarifikasi, dan penyuluhan kepada pasiennya (ibu hamil). Pemberian informasi mengenai persiapan menyusui penting untuk disampaikan, khususnya mengenai anjuran dan larangan yang dilakukan. Bagi pasien yang mempunyai riwayat kegagalan laktasi pada kehamilan sebelumnya, perlu dirujuk untuk konsultasi pranatal kepada spesialis laktasi (Varney dkk, 2008).

Puskesmas Kota Gede I terletak di Kota Yogyakarta yaitu salah satu kabupaten yang berada di DIY, dengan pencapaian target ASI eksklusif paling rendah (Dinkes DIY, 2016). Dari data awal yang didapatkan oleh peneliti, diketahui presentase bayi yang diberikan ASI eksklusif sebanyak 54,00 $\%$ (2015), sedangkan di tahun 2016 terjadi penurunan sebanyak 45,68\%. 
Dari angka tersebut di atas diketahui bahwa pada di tahun 2015-2016 terjadi penurunan sebanyak $8,32 \%$.

Penurunan angka ASI eksklusif di Puskesmas Kota Gede I disebabkan karena beberapa faktor yaitu banyaknya ibu yang mempunyai pekerjaan di luar rumah dan kurangnya pengetahuan pengelolaan atau manajemen laktasi termasuk didalamnya adalah mengenai tata cara penyimpanan dan pemberian ASI perah. Peneliti juga melakukan wawancara kepada 8 ibu hamil trimester III yang sedang melakukan ANC (antenatal care) di Puskesmas. Dari anamnesa diperoleh hasil 5 dari 8 responden tersebut kurang mengetahui materi ASI eksklusif.

Penelitian ini mempunyai tujuan untuk mengetahui apakah terdapat korelasi antara tingkat pendidikan dan umur, dengan pengetahuan seseorang tentang ASI eksklusif di Puskesmas Kota Gede I Yogyakarta.

\section{METODE PENELITIAN}

Penelitian ini menggunakan metode Survey Analitik, dengan rancangan Cross Sectional. Populasi yang digunakan yaitu seluruh ibu hamil trimester III yang melakukan ANC di
Puskesmas Kota Gede I, Yogyakarta selama 1 bulan sebanyak 30 orang.

Besar sampel berjumlah 30 orang dengan memakai teknik sampling jenuh. Menurut Sugiyono (2007), sampling jenuh merupakan teknik pengambilan sampel dengan menggunakan seluruh populasi yang ada dikarenakan jumlah populasi yang relative sedikit. Data di analisis secara univariat dan bivariat dengan menggunakan uji statistik $C h i$ Square.

\section{HASIL DAN PEMBAHASAN}

Tabel 1. Distribusi Karakteristik Responden

\begin{tabular}{llcc}
\hline No & \multicolumn{1}{c}{$\begin{array}{c}\text { Karakteristik } \\
\text { Responden }\end{array}$} & f & $\%$ \\
\hline 1 & Pengetahuan & & \\
& Kurang & 14 & 46,7 \\
& Baik & 16 & 53,3 \\
& $\quad$ Total & 30 & 100 \\
2 & Pendidikan & & \\
& Rendah & 10 & 33,3 \\
& Tinggi & 20 & 66,7 \\
& $\quad$ Total & 30 & 100 \\
& Umur & & \\
& Tidak Reproduktif & 9 & 30.0 \\
& Reproduktif & 21 & 70.0 \\
& $\quad$ Total & 30 & 100 \\
\hline
\end{tabular}

Tabel 1 menunjukkan karakteristik responden menunjukkkan sebagian besar responden tingkat pendidikannya tinggi yaitu 20 responden (66.7\%), berumur usia reproduktif sebanyak 21 responden $(70.0 \%)$, dan berpengetahuan baik yaitu sebanyak 16 responden $(53,3 \%)$. 
Tabel 2. Korelasi antara Pendidikan dengan Pengetahuan Ibu tentang ASI Eksklusif

\begin{tabular}{ccccccccc}
\hline & \multicolumn{9}{c}{ Pengetahuan } \\
Pendidikan & \multicolumn{2}{c}{ Kurang } & \multicolumn{2}{c}{ Baik } & \multicolumn{2}{c}{ Total } & $\begin{array}{c}\text { Nilai } \\
p\end{array}$ & $\begin{array}{c}\text { Risk } \\
\text { Estimate }\end{array}$ \\
& $\mathrm{n}$ & $\%$ & $\mathrm{~N}$ & $\%$ & $\mathrm{n}$ & $\%$ & \\
\hline Rendah & 8 & 22,22 & 2 & 5,56 & 10 & 33,33 & & \\
Tinggi & 6 & 16,67 & 14 & 38,89 & 20 & 66,67 & 0,019 & 9,33 \\
Total & & & & & 30 & 100 & & \\
\hline
\end{tabular}

Tabel 2 menunjukkan sebagian besar responden tingkat pendidikannya rendah dalam kategori pengetahuan kurang baik yaitu sebanyak 8 responden $(22.22 \%)$, dan responden yang berpendidikan tinggi dalam kategori pengetahuan baik yaitu sebanyak 14 responden $(38.89 \%)$.

Berdasarkan hasil analisa data pada variabel tingkat pendidikan, didapatkan data kebanyakan responden tingkat pendidikannya tinggi dan dalam kategori pengetahuan baik yaitu terdapat 14 responden $(38.89 \%)$, serta didapatkan nilai p sebesar 0.019 yang berarti terdapat korelasi antara pendidikan dengan pengetahuan ibu tentang ASI eksklusif. Pendidikan dapat memengaruhi pengetahuan ibu dengan nilai odd ratio sebesar 9.33, yang berarti responden yang tamat SMA mempunyai kemungkinan pengetahuannya $9.33 \mathrm{x}$ lebih baik apabila dibandingkan dengan yang berpendidikan rendah (tidak tamat SMA).
Responden yang berpengetahuan baik dapat dipengaruhi karena tingkat pendidikan. Pendidikan menjadi faktor penting yang dapat memengaruhi pengetahuan (Notoatmodjo, 2010). Pendidikan diperlukan karena dapat memengaruhi seseorang dalam bertindak. Orang yang pendidikannya tinggi tentunya akan dapat lebih memahami dan menerima masukan atau ide-ide baru dibandingkan dengan yang tidak mengenyam pendidikan, sehingga hal tersebut akan memengaruhi banyak atau sedikitnya ilmu yang diperoleh (Setianingsih\&Haryono, 2014).

Penelitian ini menunjukkan bahwa tingginya pengetahuan Ibu sangat memengaruhi pemberian ASI eksklusif. Menurut Notoatmodjo (2010) terdapat 2 faktor yang sangat terkait dengan pengetahuan yaitu faktor yang berasal dari dalam dan dari luar. Yang termasuk faktor dari dalam adalah pendidikan, pekerjaan, umur, pengalaman, sosial ekonomi, paritas, sedangkan yang dari 
luar adalah lingkungan dan budaya. Dari data yang didapat, responden kebanyakan memiliki wawasan yang baik tentang ASI, hal tersebut dapat disebabkan karena faktor pendidikan Ibu yang cukup tinggi yaitu pendidikan terakhirnya SMA.

Menurut Notoatmodjo (2010), semakin tinggi pendidikan seseorang maka akan semakin mudah dalam mendapatkan informasi dan akhirnya bisa memengaruhi perilaku seseorang. Pendidikan dapat membuat seseorang mengambil keputusan untuk mencari pengetahuan yang lebih luas lagi sehingga akan menjadikan kebenaran terhadap informasi yang didapatkan.
Seseorang yang mempunyai wawasan lebih akan membentuk suatu keyakinan untuk dapat melakukan perilaku tertentu.

Sesuai dengan penelitian Widiyanto dkk (2012) tentang Hubungan Pendidikan dan Pengetahuan Ibu tentang ASI Eksklusif dengan Sikap Terhadap Pemberian ASI Eksklusif, menunjukkan bahwa ada hubungan yang bermakna antara pendidikan dan pengetahuan dengan sikap pemberian ASI eksklusif. Uraian tersebut memperlihatkan bahwa pendidikan mempunyai pengaruh yang sangat besar terhadap pengetahuan seseorang.

Tabel 3. Korelasi antara Umur dengan Pengetahuan Ibu tentang ASI Eksklusif

\begin{tabular}{|c|c|c|c|c|c|c|c|c|}
\hline \multirow{3}{*}{ Umur } & \multicolumn{6}{|c|}{ Pengetahuan } & \multirow{3}{*}{$\begin{array}{c}\text { Nilai } \\
p\end{array}$} & \multirow{3}{*}{$\begin{array}{c}\text { Risk } \\
\text { estimate }\end{array}$} \\
\hline & \multicolumn{2}{|c|}{ Kurang } & \multicolumn{2}{|c|}{ Baik } & \multicolumn{2}{|c|}{ Total } & & \\
\hline & $\mathrm{n}$ & $\%$ & $\mathrm{~N}$ & $\%$ & $\mathrm{n}$ & $\%$ & & \\
\hline Tidak Reproduktif & 8 & 22,22 & 1 & 2,78 & 9 & 30 & & \\
\hline Reproduktif & 6 & 16,67 & 15 & 41,67 & 21 & 70 & 0,004 & 20,0 \\
\hline Total & & & & & 30 & 100 & & \\
\hline
\end{tabular}

Tabel 3 responden kebanyakan masuk dalam kategori usia tidak reproduktif yaitu $<20$ tahun atau $>35$ tahun dalam kategori kurang baik yaitu sebanyak 8 responden $(22.22 \%)$, dan yang berusia reproduktif yaitu 20-35 tahun termasuk ke dalam kategori baik yaitu 15 responden (41.67\%).
Berdasarkan hasil analisa data pada variabel umur, didapatkan nilai $p$ sebesar 0.004. Nilai signifikasi di bawah 0.05 mempunyai arti terdapat korelasi antara umur dengan pengetahuan, sehingga dapat diartikan bahwa umur dapat memengaruhi tingkat pengetahuan ibu mengenai ASI eksklusif dengan nilai odd ratio sebesar 
20.0. Dengan begitu, ibu yang memiliki usia reproduktif (20-35 tahun) mempunyai kemungkinan pengetahuan 20.0x lebih banyak daripada dengan usia yang tidak reproduktif $(<20$ tahun atau $>35$ tahun).

Hasil penelitian menyatakan banyak responden yang masih berusia reproduktif termasuk ke dalam kategori berpengetahuan baik yaitu terdapat sejumlah 15 responden (41.67\%). Hal tersebut sesuai dengan teori bahwa, usia seseorang menjadi faktor yang dapat memengaruhi tingkat pengetahuan. Seseorang yang berumur produktif akan cenderung lebih mudah mencerna dalam hal proses penerimaan pengetahuan dibandingkan seseorang yang berumur tidak produktif. Dari penjelasan di atas maka umur dapat dikatakan sebagai faktor yang berpengaruh pada penelitian ini dikarenakan dengan semakin bertambah tua umur seseorang maka akan semakin luas informasi dan pengalaman yang diperoleh (Notoatmodjo, 2012).

Sebagaimana dengan teori dari Notoatmodjo (2010), dengan bertambahnya umur seseorang, maka akan semakin baik proses perkembangan mental seseorang tersebut, akan tetapi pada umur tertentu
$(<20$ tahun $)$ proses perkembangan mental ini belum sebaik ketika dalam rentangan umur pada level yang matang (20-35 tahun), akan tetapi juga pada umur yang sudah mulai memasuki usia lanjut, akan terjadi pengurangan pada kemampuan dalam hal mengingat sesuatu.

Umur seseorang yang terhitung dari mulai dia dilahirkan ke dunia sampai dengan dia berulang tahun pada tahun selanjutnya adalah disebut dengan umur (Wawan, 2011). Umur yang semakin dewasa, tingkat kekuatan dan tingkat kematangannya akan menjadi lebih bagus, baik itu dalam hal berfikir maupun dalam hal bekerja. Seseorang yang lebih dewasa cenderung akan banyak dipercaya daripada orang yang belum dewasa. Kedewasaan seseorang sangat dipengaruhi oleh pengalaman. Pada penelitian ini banyak responden berumur antara 20-35 tahun, dimana responden telah memiliki pengalaman yang sangat banyak baik itu dalam berfikir maupun dalam beraktivitas, usia tersebut sangat membantu responden dalam menerima wawasan tentang sesuatu hal yang lebih baik lagi.

Daya tangkap seseorang bisa dipengaruhi oleh umur. Ibu hamil trimester III yang memiliki daya 
tangkap yang cukup dalam hal penerimaan informasi tentu akan memiliki pemikiran yang baik terhadap sesuatu yang dia diterima, termasuk disitu tentang manfaat serta penerapan ASI eksklusif kepada bayinya (Ariani, 2014).

Pertambahan usia seseorang dengan kematangan jiwa sangat erat kaitannya terhadap tingkat kemampuan analisa permasalahan atau kejadian-kejadian fenomena saat ini. Dengan usia yang makin bertambah, maka diharapkan seseorang individu mampu belajar untuk selalu mengembangkan wawasan serta skillnya sesuai dengan kematangan usianya (Lestari, 2013). Kematangan fisik, psikis, dan sosial seseorang ditentukan salah satunya oleh faktor umur. Umur menjadi faktor penentu terkait pengalaman dan luasnya pengetahuan. Karena dengan bertambah tuanya umur seseorang, semakin bertambah pula pengetahuan yang didapat.

\section{SIMPULAN DAN SARAN}

Terdapat korelasi antara pendidikan dengan pengetahuan Ibu hamil trimester III tentang ASI eksklusif di Puskesmas Kota Gede I Yogyakarta dengan nilai $\mathrm{p}$ sebesar 0.019 dan nilai odd ratio sebesar
9.33. Terdapat korelasi antara umur dengan pengetahuan Ibu hamil trimester III tentang ASI eksklusif di Puskesmas Kota Gede I Yogyakarta dengan nilai p sebesar 0.004 dan nilai odd ratio sebesar 20.0 .

Diharapkan para tenaga kesehatan bisa meningkatkan kualitas pelayanannya terutama dalam pemberian konseling terkait ASI eksklusif dan manajemennya pada saat ibu hamil melakukan ANC (antenatal care), sehingga ibu hamil dapat bertambah pengetahuan dan wawasan serta dapat menerapkannya.

\section{DAFTAR PUSTAKA}

Ariani, P. A. 2014. Aplikasi Metode Penelitian Kebidanan dan Kesehatan Reproduksi. Yogyakarta : Nuha Medika

Budiasih, K. S. 2008. Handbook Ibu Menyusui. Jawa Barat : Hayati Qualita.

Departemen Kesehatan, 2013. Pusat Data dan Informasi Kementerian Kesehatan RI. Jakarta : Departemen Kesehatan.

Dinas Kesehatan Daerah Istimewa Yogyakarta, 2015. Profil kesehatan Daerah Istimewa Yogyakarta. Yogyakarta : Dinas Kesehatan Daerah Istimewa Yogyakarta

Lestari, D. dkk. 2013. Hubungan Tingkat Pengetahuan Ibu Tentang Air Susu Ibu dan Pekerjaan Ibu dengan Pemberian ASI Eksklusif 
di Kelurahan Fajar Bulan. Jurnal Kedokteran Unila, V2(4) : 88-99.

Notoatmodjo, S. 2010. Ilmu Perilaku Kesehatan. Jakarta: PT Rineka Cipta.

\section{Metodologi}

Penelitian Kesehatan. Jakarta : PT Rineka Cipta.

Proverawati, A. dan Rahmawati, E. 2010. Kapita Seleksta ASI dan Menyusui. Yogyakarta : Nuha Medika.

Setianingsih, S. dan Haryono, R. 2014. Manfaat ASI Eksklusif untuk Buah Hati Anda. Yogyakarta : Gosyen Publishing.
Sugiyono. 2007. Metode Penelitian. Bandung : Alfabeta.

Varney, H., Kriebs, J. M., dan Gegor, C. L.. 2008. Buku Ajar Asuhan Kebidanan Volume 2. Jakarta : EGC.

Wawan, A. dkk. 2011. Teori dan Pengukuran Pengetahuan, Sikap dan Perilaku Manusia. Yogyakarta : Nuha Medika.

Widiyanto, S. dkk. 2012. Hubungan Pendidikan dan Pengetahuan Ibu Tentang ASI Eksklusif dengan Sikap Terhadap Pemberian ASI Eksklusif. Jurnal kedokteran Muhammadiyah, V1(1) : 25-29. 